\title{
COMMENTARY
}

\section{Designing and managing distributed learning: we're all in this together}

Part of Special Series: COVID-19 and Online Health Professional Education

\section{AUTHORS}

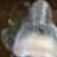

Janet Grant ${ }^{1}$, Academic Director *

Leonard G Grant ${ }^{2}$, Academic Course Manager

\section{CORRESPONDENCE}

*Prof Janet Grant janet@cenmedic.net

\section{AFFILIATIONS}

1,2 CenMEDIC, 27 Church Street, Hampton, Middlesex TW12 2EB, UK

\section{PUBLISHED}

11 June 2021 Volume 21 Issue 2

HISTORY

RECEIVED: 3 June 2020

REVISED: 19 March 2021

ACCEPTED: 1 April 2021

\section{CITATION}

Grant J, Grant LG. Designing and managing distributed learning: we're all in this together. Rural and Remote Health 2021; $21: 6171$. https://doi.org/10.22605/RRH6171

\section{ETHICS APPROVAL}

No ethics approval required

This work is licensed under a Creative Commons Attribution 4.0 International Licence

\section{FULL ARTICLE:}

Distance learning methods have long been an integral part of medical education in rural and remote settings ${ }^{\mathbf{1 - 4}}$. The global coronavirus crisis has stimulated a rapid move from predominantly face to face (or understood as face-to-face) courses to being delivered online (sometimes referred to as distance learning) in

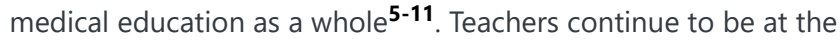
forefront of the time-consuming and labour-intensive process, which also requires considerable student engagement, properly supported by effective management.
As thinking and practice in distance learning have developed, the importance of the institution, student support and management have changed the key concept from distance learning to distributed learning ${ }^{\mathbf{1 2}}$. This term implies that, rather than the central institution being the distribution hub for teaching and learning resources delivered to remote learners, the institution itself distributes its functions to be near those students. Miller recently stated concerns about the challenges of remote supervision ${ }^{\mathbf{1 3}}$. This article explores the implications of this 
conceptualisation, and its synergy with the conditions of training in remote and rural settings is explored.

\section{Distributed learning and whole systems}

Distance learning suggests that a central institution provides learning materials and processes to students who are remote from that central location. Distributed learning suggests that the institution itself is available locally by, for example, appointing teachers who are near the location of students, or by setting up regional branch offices that offer physical meeting and study spaces and academic advisers. Medical education itself is a distributed system, with a central medical school, and then hospitals and primary care facilities at a distance. Students themselves are distributed to these, where they have clinical supervisors and other teachers. Community-, rural- and remoteorientated schools are examples of distributed learning.

Although this example already exists, recent responses to the global pandemic have mainly been in terms of distance learning rather than distributed learning. Sometimes, what is presented as distance learning actually has elements of distributed learning, such as local teachers or central teachers visiting rural sites ${ }^{\mathbf{1 4}}$. Sometimes, the need for a managed educational system is recognised ${ }^{\mathbf{1 5}}$. It seems timely, therefore, to examine the nature of distributed learning as a development paradigm.

Distance and distributed learning are different educational mindsets. The 'conversion and delivery' model tends to imagine how campus-based teaching can be translated into an online mode for circulation to students. The 'distributed learning' model ${ }^{\mathbf{1 6}}$ approaches the design of an entire educational infrastructure and the individual learning process that it hopes to encourage and support.

In times of crisis, there is a need for a fast response, which has been (and had to be, given the desire for courses to continue uninterrupted) a 'conversion and delivery' model ${ }^{\mathbf{1 7}}$. So, while the current conversion of teaching to online methods settles down, the strategic need will be to develop this into a more effective, designbased and institutionally distributed learning model with appropriate management, support and quality assurance so that, no matter how remote the students are, they are always relatively near some in-person part or representative of their institution.

Effective distributed learning therefore requires a whole-systems approach. This recognises that any complex organisation comprises a set of interrelated, interdependent components such that parts of that system cannot effectively be addressed in isolation from all the other parts ${ }^{\mathbf{1 8}}$. Whole systems therefore demand management.

Important aspects of the whole system of distributed learning include contextual analysis, a model of learning (which might be different for different elements or might use a more generic multimedia learning theory ${ }^{\mathbf{1 9}}$ ), carefully designed teaching and learning methods, a delivery and management system, and student-student and teacher-student interactions. If these immediate responses to the current crisis are designed into a well- managed whole system, a sustainable model of distributed blended learning can be established for the longer term ${ }^{\mathbf{2 0}}$.

The technologies being used to adapt to the current crisis are already used in campus-based learning ${ }^{\mathbf{2 1 , 2 2}}$. These include teleteaching and telemedicine for clinical placements ${ }^{\mathbf{2 3}}$, mobile technologies such as cell phones for teaching clinical medicine $\mathbf{2 4 , 2 5}^{\mathbf{2}}$, and repositories of patient interviews ${ }^{\mathbf{2 6}}$ versioned for teaching purposes. This blurring of the differences between campus-based and distributed learning in medical education might imply that the two are much the same, except for the lack of centralised physical presence of the students. If that is so, then simple conversion of campus-based materials to technology-based ones might seem logical.

But distributed learning is not the recreation or simulation of the campus-based experience. It is quite a different entity, within a different whole system, demanding different considerations of management and student support. The 'dark side' of technology for learning has been illuminated ${ }^{\mathbf{2 7}}$.

\section{Distributed learning in regional, rural and remote contexts}

To ensure that distributed students experience as rich a learning experience as centrally located students, educational design begins with a contextual analysis of the locations where learners find themselves ${ }^{\mathbf{2 8}}$, matching these with the wide range of teaching methods, support, feedback and student-student or teacher-student communication processes that are available. If technology is unreliable, then asynchronous learning, and methods that enable downloaded materials, especially print, for later study, become more important. Simpler technologies such as telephone tutorials can be effective ${ }^{\mathbf{2 9}}$. The best teaching medium is not a matter of fashion but of pragmatic, skilled use of a blend of methods ${ }^{30}$.

The contextual analysis for health professions students in remote and rural locations must also include the availability of local mentors and supervised practical experience ${ }^{\mathbf{3 1}}$, which should be an integral part of an effective distributed health professions institution. Learning clinical skills, and implementing reliable and valid assessments of clinical competence, may well depend on the appointment, training, support and quality assurance of local clinical teachers.

Embeddedness in the local healthcare system potentiates an enriched learning experience, but also demands that local healthcare colleagues be supported by the central institution in terms of supervision and feedback skills development, learning materials, exercises and resources, which provide the rich learning that addresses all intended learning outcomes, but also will ensure that all students will benefit from the same quality of learning, wherever they are $^{\mathbf{3 2}}$.

If we start with the narrow view that distributed learning is online learning, the enterprise may well fail by excluding some students, or offering an impoverished educational experience that will, in the end, be alienating. Despite its widespread use, research is only just starting to suggest that student engagement and achievement is a 
complex, emotionally influenced process ${ }^{33,34}$.

Given the contextual analysis, the task of designing a distributed learning system is to plan an unambiguous and engaging flow of rich and varied learning experiences that match the intended learning outcomes, that provide regular waypoints, interactions and feedback to ensure student progress, and that allow teachers in the central institution to support both each student and each local mentor or supervisor ${ }^{31}$. The right role for each component, whether technology based or not, must be found to support student engagement ${ }^{35}$.

\section{Quality and the student experience}

An indication of the components of the whole system of distributed learning is found in a framework for its quality assurance ${ }^{\mathbf{3 6}}$, distilled from regulatory standards ${ }^{37}$. Such a framework might address the technical and study context and the needs of students, teachers, the healthcare system and regulatory bodies. If learners are distributed to local healthcare facilities ${ }^{\mathbf{3 1}}$, then carefully managed and quality assured partnerships are required between the school and the healthcare system and any clinical staff who might become teachers or supervisors ${ }^{38,39}$.

Where students may not be able to attend virtual lectures or seminars at a set time, we can allow them to continue learning by enabling access to appropriately designed ${ }^{\mathbf{3 8 , 3 9}}$ materials at a time convenient to them. Making this switch quickly means prioritising accessible resources. Webinars and live events may seem easy and appealing but sitting at a computer for several hours may not be possible for learners or teachers. Students may not have access to reliable internet to participate; is there a way of taking part only by text?

Quality indicators for distributed learning might be generated by each institution, reflecting its own purpose and context. Such qualities should deflect possible confusion and disengagement among students, and address what is required to establish and maintain the whole distributed system. This might include $\mathbf{2 1}^{\mathbf{2 1}}$
- awareness of the needs of students, teachers, the healthcare system and regulatory bodies

- a contextual analysis of where and how the students will learn to ensure synchrony between their physical and technological resources and the course design

- a clear curriculum and timetable with linked learning resources, methods and events

- training and support for central teachers and administrators in materials development, design and delivery, teaching, assessment and feedback

- carefully managed partnerships with local institutions, organisations or services where students might be based or offered clinical experience

- expert development of engaging course materials by distance learning and subject specialists

- drafting and testing of all course components

- central and local student induction and support systems

- regular contact between students, and with students from central academic, clinical and administrative staff

- formative assessments with personalised feedback

- student records to chart progress

- selection, training, support and monitoring of local teachers and clinical sites, in relation to teaching, support, assessment and feedback

- regular program evaluation and course review.

This list of qualities assumes a long-term distributed system, integrated with the local healthcare system. This requires quality assurance of the opportunities that those locations offer, and relevant support for the clinicians who will be teachers and supervisors ${ }^{\mathbf{4 0}}$. Distributed learning can enable students to learn clinical skills ${ }^{\mathbf{4 1 - 4 3}}$ and laboratory sciences ${ }^{\mathbf{4 4}}$.

There is always a danger of losing distributed students ${ }^{\mathbf{4 5}}$. They can lose their way through materials that are poorly designed $\mathbf{4 6 , 4 7}$. They can misunderstand, drift and feel isolated. Technology and library access can fail. They might miss interaction with peers and teachers. However, there are parallel challenges for students learning face to face.

A cardinal rule for designers is to imagine the student experience and design a clear flow of varied learning that engages, guides, maintains interest and offers flexibility without leaving the student rudderless. The standard stages of educational design apply ${ }^{\mathbf{3 0}}$.

- a carefully planned blend of elements, mapped onto the curriculum to ensure coverage and learner engagement

- emphasis on prepared workbooks, feedback, learning activities, communication, monitoring and support

- deliberate attempts to create a community of learners.

\section{Assumptions about students}

It seems common to assume that students are well equipped to learn from technology-based materials. But although they may be adept at navigating technology, that is not the same as learning from it ${ }^{\mathbf{4 8}}$. There is no evidence that young people's cognitive learning processes have changed or can change. Learning is still the systematic creation of robust, well-organised and useable 
cognitive structures in memory ${ }^{\mathbf{4 9}-53}$, best facilitated by equally well-organised learning resources and processes.

Technology is simply a medium. The ideas of learners as selfeducators, digital natives, with specific learning styles have been convincingly presented as urban myths ${ }^{\mathbf{5 4}}$. Indeed, learners often prefer print to other modalities ${ }^{\mathbf{5}}$. Specially prepared print resources ${ }^{23}$ must be part of the rich blend.

\section{Managing at a distance}

Vital to any course is its management. While lecturers and teachers have been made responsible for delivering their work in an entirely new medium, who should transform all the related metadata? How do/should we measure attendance and engagement? How could we change assessments and assessment criteria, if they need to change ${ }^{56}$ ?

In terms of managing a distributed learning course, it would be an inappropriate burden to place these on those who are also delivering the course. Employing a skilled management person or team is essential.

\section{Managing learners and teachers}

One of the concerns around online delivery is that it can tip too quickly into surveillance ${ }^{\mathbf{5 7}}$, and so this is something to guard against. Management decisions might include the collection of data ${ }^{58}$ on:

- how students interact with the online materials

- marks for any assessments other than summative assessments

- frequency of logging on to the sites.

But which of these enhances either the course or the student experience?

The materials are provided for students to engage with when they are able and need to do so. It helps clarity of the learning pathway to offer such materials in a pre-defined order, and within a series of deadlines for formative and summative assignments that give personalised feedback, mark progress and deflect drift from the timetable.

Students should always know:

- what they have to do

- when they have do to it

- how to ask for help

- how we will communicate with them.

Just as students should understand their learning pathways and deadlines, central and distributed teachers should know:
- what they have to do

- when they have to do it

- how to ask for help

- how students will communicate with them.

\section{Distributed learning, the university and the market}

Although there has been a firefighting reaction to the COVID-19 pandemic, we would posit that a strategic switch to online or blended distributed learning should not happen quickly, or without planning, thought and care. Far from being firefighting or an opportunity to retain or develop educational markets, this is an opportunity for medical education to radically rethink its classrooms and its pedagogy. Who has access to the classroom and the materials? How are those materials presented? What is fundamental and important to your course? Who is now able to access your teaching who was previously excluded? Who is now excluded?

Several further issues arise. Who now owns the material? When a lecturer writes and records a lecture, uploads that lecture to their university learning management system, along with their lecture notes, does that material now belong to the university? Can it be used again, without permission or payment?

It is worth considering what this could mean for university employees who are asked, currently, to split their time between teaching, research and service. If the university considers teaching a one-time action, such that a course can be repeated to every cohort of students with little or no further input from educators, then what would this mean for staff? What effects would this have on their ability to research? Perhaps the politically and economically motivated devaluing of the 'symbiotic relationship between teaching and research' $\mathbf{5 9}^{\mathbf{9}}$ is one that should be resisted in the era of distributed learning.

Underpinning these issues must be a costing model for distributed learning ${ }^{\mathbf{6 0}}$. Design and delivery of each element, and of the totality, requires time, adjustments to central academic and administrative workloads, training and support for central and peripheral academics in their new roles, funding and management ${ }^{\mathbf{6 1}}$.

The coronavirus pandemic has increased the tension in an existing contradiction: is the university a site of learning and research or an economy? These two modes of the university have mutually exclusive desires: to foster an environment of support, listening and enquiry and to continue its functions to drive continually increasing income generation and output.

Although the design of educational resources for distributed learning is a key factor, we must not lose sight of the wider implications within the whole system.

\section{REFERENCES:}

1 Sargeant JM. Medical education for rural areas: opportunities and challenges for information and communications technologies.
Journal of Postgraduate Medicine 2005; 51(4): 301-307.

2 Lillis S, Gibbons V, Lawrenson R. The experience of final year 
medical students undertaking a general practice run with a distance education component. 2010; 10: 1268. Available: web link (Accessed 29 May 2021). DOI link, PMid:20345189

3 Tesson G, Strasser R, Pong RW, Curran V. Advances in rural medical education in three countries: Canada, The United States and Australia. Rural and Remote Health 2005; 5(4): 397. Available: web link (Accessed 30 May 2021). DOI link, PMid:16283826

4 Strasser RP, Lanphear JH, McCready WG, Topps MH, Hunt DD, Matte MC. Canada's new medical school: the northern Ontario School of Medicine: social accountability through distributed community engaged learning. Academic Medicine 2009; 84(10): 1459-1564. DOI link, PMid:19881443

5 Seymour-Walsh AE, Bell A, Weber A, Smith T. Adapting to a new reality: COVID-19 coronavirus and online education in the health profession. Rural and Remote Health 2020; 20: 6000. Available: web link (Accessed 29 May 2021). DOI link

6 Al-Balas M, Al-Balas HI, Jaber HM, Obeidat K, Al-Balas H, Aborajooh EA, et al. Distance learning in clinical medical education amid COVID-19 pandemic in Jordan: current situation, challenges, and perspectives. BMC Medical Education 2020; 20(1): 341. DOI link, PMid:33008392

7 Jodheea-Jutton A. Reflection on the effect of COVID-19 on medical education as we hit a second wave. MedEdPublish 2021; 10(1): 1-10. DOI link

8 Khan MJ, Zaghw A, Tageldin T, Elarref M. Advanced Anesthesiology and Perioperative Medicine (AAPM) Fellowship Program in Hamad Medical Corporation during COVID-19 pandemic: adapting and redesigning the Fellowship Program. MedEdPublish 2021; 3619. DOI link

9 Elsalem L, Al-Azzam N, Jum'ah AA, Obeidat N. Remote E-exams during Covid-19 pandemic: a cross-sectional study of students' preferences and academic dishonesty in faculties of medical sciences. Annals of Medicine and Surgery 2021; 62: 326-333. Available: web link, PMid:33520225

10 Taylor D, Grant J, Hamdy H, Grant L, Marei H, Venkatramana M. Transformation to learning from a distance. MedEdPublish 2020; 9: 2999. DOI link

11 Shachar M, Neumann Y. Twenty years of research on the academic performance differences between traditional and distance learning: summative meta-analysis and trend. MERLOT Journal of Online Learning and Teaching 2010; 6(2): 318-334.

12 van Schalkwyk SC, Couper ID, Blitz J, de Villiers MR. A framework for distributed health professions training: using participatory action research to build consensus. BMC Medical Education 2020; 20: 154. DOI link, PMid:32410654

13 Miller L. Remote supervision in primary care during the Covid-19 pandemic - the 'new normal'? Education for Primary Care 2020; 31(6): 332-336. DOI link, PMid:32757821

14 Vyas R, Zachariah A, Swamidasan I, Doris P, Harris I. Role of distance-learning modules and contact sessions in developing knowledge and skills of junior doctors for practicing effectively in rural hospitals in India. Medical Teacher 2013; 35(2): 170. DOI link, PMid:23146077
15 Baker A, Hardie L, Somerville S, Ker J. Analysis of the use of a mobile simulation unit using the principles of a managed educational network. [Internet]. Rural and Remote Health 2021; 21(1): 5670. Available: web link (Accessed 15 March 2021).

16 Victor S, Hart S. Distributed learning: a flexible learning and development model. E-Learn: World Conference on E-Learning in Corporate, Government, Healthcare, and Higher Education 2016; 2016(1): 281-290.

17 Dill E, Fischer K, McMurtie B. As coronavirus spreads, the decision to move classes online is the first step. What comes next? 2020. Available: web link (Accessed 29 May 2020).

18 Morgan P. The idea and practice of systems thinking and their relevance for capacity development. 2005. Available: web link (Accessed 15 March 2021).

19 Mayer R. Applying the science of learning: evidence-based principles for the design of multimedia instruction. American Psychologist 2008; 63(8): 760-769. DOI link, PMid:19014238

20 Dziuban C, Graham CR, Moskal PD, Norberg A, Sicilia N. Blended learning: the new normal and emerging technologies. International Journal of Educational Technology in Higher Education 2018; 15(1): 3. DOI link

21 Naidu S. Designing instruction for e-learning environments. In: MG Moore, WG Anderson (Eds). Handbook of distance education. Mahwah, NJ: Lawrence Erlbaum Associates, 2003; 349-365.

22 Moran J, Briscoe G, Peglow S. Current technology in advancing medical education: perspectives for learning and providing care. Academic Psychiatry 2018; 42(6): 796-799. DOI link, PMid:29949053

23 Hollander JE, Carr BG. Virtually perfect? Telemedicine for Covid-19. New England Journal of Medicine 2020; 382(18): 1679-1681. DOI link, PMid:32160451

24 Masters K, Ellaway RH, Topps D, Archibald D, Hogue RJ. Mobile technologies in medical education: AMEE Guide No. 105. Medical Teacher 2016 Jun 2; 38(6): 537-549. DOI link, PMid:27010681

25 Vyas R, Albright S, Walker D, Zachariah A, Lee MY. Clinical training at remote sites using mobile technology: An India-USA partnership. Distance Education 2010; 31(2): 211-226. DOI link

26 Mian A, Khan S. Medical education during pandemics: a UK perspective. BMC Medicine 2020; 18: 100. DOI link, PMid:32268900

27 Delgaty L, Fisher J, Thomson R. The 'dark side' of technology in medical education. MedEdPublish 2017; 6(2): 978. DOI link

28 Benson R, Samarawickrema G. Teaching in context: some implications for e-learning design. ASCILITE 2007 - the Australasian Society for Computers in Learning in Tertiary Education 2007; 61-70.

29 Finger G, Rotolo C. Telephone teaching: towards constructivist teaching for rural and remote students. Fremantle, WA: Annual Conference of the Australian Association for Research in Education, 2001.

30 Grant J. Distance learning in medical education. In: P Bhuiyan, N Rege, A Supe (Eds). The Art of Teaching Medical Students. 3rd edn. Newmarket, Suff: Reed Elsevier, 2014. 
31 Grant J. Using open and distance learning to develop clinical reasoning skills. In: J Higgs, M Jones, S Loftus, N Christensen (Eds). Clinical reasoning in the health professions. 3rd edn. Amsterdam: Elsevier, 2008.

32 Kilminster S, Cottrell D, Grant J, Jolly B. AMEE Guide No. 27: Effective educational and clinical supervision. Medical Teacher 2007; 29(1): 2-19. DOI link, PMid:17538823

33 Artino AR, Jones KD. Exploring the complex relations between achievement emotions and self-regulated learning behaviors in online learning. Internet and Higher Education 2012; 15(3): 170-175. DOI link

34 Artino AR. Think, feel, act: motivational and emotional influences on military students' online academic success. Journal of Computing in Higher Education 2009; 21(2): 146-166. DOI link

35 Michalski C, Cowan M, Bohinsky J, Dickerson R, Plochocki J. Mixed reality technology influences motivation for learning in medical students. MedEdPublish 2020; 9: 3177. DOI link

36 Grant J. Distance learning: a response to overcome current challenges in medical education? Towards Unity for Health 2001; April: 21-23.

37 Open and Distance Learning Council. ODLQC Standards. New Delhi: Open and Distance Learning Council, 2012.

38 Goldie JGS. Connectivism: a knowledge learning theory for the digital age? Medical Teacher 2016; 38(10): 1064-1069. DOI link, PMid:27128290

39 Grant J, Zachariah A. Distance learning for medical teachers: a short course. In: J Dent, RM Harden (Eds). A practical guide for medical teachers. Amsterdam: Elsevier, 2009.

40 Ladhani Z, Chhatwal J, Vyas R, Iqbal M, Tan C, Diserens D. Online role-playing for faculty development. Clinical Teacher 2011; 8(1): 31-36. DOI link, PMid:21324070

41 McCutcheon K, Lohan M, Traynor M, Martin D. A systematic review evaluating the impact of online or blended learning vs. face-to-face learning of clinical skills in undergraduate nurse education. Journal of Advanced Nursing 2015; 71(2): 255-270. DOI link, PMid:25134985

42 Kelly M, Lyng C, McGrath M, Cannon G. A multi-method study to determine the effectiveness of, and student attitudes to, online instructional videos for teaching clinical nursing skills. Nurse Education Today 2009; 29(3): 292-300. DOI link, PMid:19121875

43 Gormley G, Collins K, Boohan M, Bickle I, Stevenson M. Is there a place for e-learning in clinical skills? A survey of undergraduate medical students' experiences and attitudes. Medical Teacher 2009; 31(1): e6-e12. DOI link, PMid:19253150

44 Richardson B, Bradshaw K, Openstem T, Collins T, Hawkridge B. Practical STEM at the Open University: the use of live video in the OpenStem Labs to innovate teaching and create a community of practical STEM students. In: J. Theo Bastiaens (Ed.). Proceedings of EdMedia + Innovate Learning. Amsterdam: Association for the
Advancement of Computing in Education (AACE), 2019; 1811-1814.

45 Sampson N. Meeting the needs of distance learners. Language Learning and Technology 2003; 7(3): 103-118.

46 Halbert C, Kriebel R, Cuzzolino R, Coughlin P, Fresa-Dillon K. Self-assessed learning style correlates to use of supplemental learning materials in an online course management system. Medical Teacher 2011; 33(4): 331-333. DOI link, PMid:21456993

47 Bettinger $\mathrm{E}$, Loeb S. Promises and pitfalls of online education. Education Next 2017; 2: 6-9.

48 Bennett S, Maton K, Kervin L. The 'digital natives' debate: a critical review of the evidence. British Journal of Educational Technology 2008; 39(5): 775-786. DOI link

49 Baddeley AD. Working memory. Oxford: Oxford University Press, 1986.

50 Bartlett FC. Remembering: a study in experimental and social psychology. Cambridge, Cambs: Cambridge University Press, 1932.

51 Von Glaserfeld E. Constructivism in education. In: T Husen, TN Postlethwaite (Eds). The International encyclopedia of education, Supplement Vol 1. Oxford/New York: Pergamon Press, 1989.

52 Bruner JS. Toward a theory of instruction. Cambridge, MA: Belkap Press, 1966.

53 Piaget J. The origins of intelligence in children. New York, NY: International University Press, 1952. DOI link

54 Kirschner PA, van Merriënboer JJG. Do learners really know best? Urban Legends in Education. Educational Psychologist 2013; 48(3): 169-183. DOI link

55 Mizrachi D. Online or print: which do students prefer? In: S Kurbanoğlu, S Špiranec, E Grassian, D Mizrachi (Eds). European Conference on Information Literacy. Dubrovnik, Croatia: Springer, 2014; 733-752. DOI link

56 Dennick R, Wilkinson S, Purcell N. AMEE guides in medical education online eAssessment AMEE GUIDE. Medical Teacher 2010; 31(3): 192-206. DOI link, PMid:19811115

$\mathbf{5 7}$ Nemorin S. Post-panoptic pedagogies: the changing nature of school surveillance in the digital age. Surveillance and Society 2017; 15(2): 239-253. DOI link

58 FAIMER Distance Learning. Distance learning. 2020. Available: web link (Accessed 29 May 2020).

59 Robertson J. Beyond the 'research/teaching nexus': exploring the complexity of academic experience. Studies in Higher Education 2007; 32(5): 541-556. DOI link

60 Rumble G (Ed.). Modeling the costs and economics of distance education. In: Handbook of distance education. London: Lawrence Erlbaum Associates, 2003; 703-716.

61 Delgaty L. A critical examination of the time and workload involved in the design and delivery of an e-module in postgraduate clinical education. Medical Teacher 2013; 35(5): e1173-e1180. DOI link, PMid:23151211 
Version of Record. 